\title{
Effect of Different Crop Establishment Methods and Irrigation Regimes on Rice (Oryza sativa L.) Yield and Water Use Efficiency
}

\author{
A. Sathish ${ }^{1 *}$, K. Avil Kumar ${ }^{2}$, P. Raghu Rami Reddy ${ }^{1}$, and M. Uma Devi ${ }^{1}$ \\ ${ }^{1}$ Water Technology Centre, College of Agriculture, Professor Jayashankar Telangana State \\ Agricultural University, Rajendranagar, Hyderabad, Telangana, India \\ ${ }^{2}$ ADR, Regional Agricultural Research Station, PJTSAU, Warangal-506007, Telangana, India \\ *Corresponding author
}

\section{A B S T R A C T}

A field experiment was conducted at Agricultural Research Institute Rajendranagar, Hyderabad during kharif 2014 to study the "Water management for different systems of rice (Oryza sativa L.) cultivation in puddled soils". The treatments comprises of three systems of cultivations (direct seeding with drum seeder, transplanting with machine and

\section{Keywords}

Different systems of rice cultivation, Yield, Water productivity.

\section{Article Info}

Accepted:

04 July 2017

Available Online:

10 September 2017 conventional transplanting) as main treatments and four irrigation regimes (irrigation of 5 $\mathrm{cm}$, when water level falls below $5 \mathrm{~cm}$ from soil surface in field water tube, irrigation of 5 $\mathrm{cm}$, when water level falls below $10 \mathrm{~cm}$ from soil surface in field water tube, irrigation of $5 \mathrm{~cm}$ at 3 days after disappearance of ponded water and recommended submergence of 2-5 $\mathrm{cm}$ water level as per crop stage). Machine transplanting recorded significantly higher grain and straw (6088 and $6954 \mathrm{~kg} \mathrm{ha}^{-1}$, respectively) yields over drum seeding method (5308 and $6295 \mathrm{~kg} \mathrm{ha}^{-1}$, respectively) and was on par with conventional transplanting method (5926 and $6886 \mathrm{~kg} \mathrm{ha}^{-1}$, respectively). Significantly higher water use efficiency $\left(4.7 \mathrm{~kg} \mathrm{~mm}^{-1}\right)$ was recorded with machine transplanting compared to drum seeding $(4.0 \mathrm{~kg}$ $\mathrm{mm}^{-1}$ ) and was on par with conventional transplanting $\left(4.5 \mathrm{~kg} \mathrm{~mm}^{-1}\right)$. Among different irrigation regimes Recommended submergence of $2-5 \mathrm{~cm}$ water level $\left(\mathrm{I}_{4}\right)$ recorded significantly higher grain and straw yield (6148 and $7039 \mathrm{~kg} \mathrm{ha}^{-1}$, respectively) and was on par with irrigation of $5 \mathrm{~cm}$ when water falls below $5 \mathrm{~cm}$ from soil surface in field water tube $\left(\mathrm{I}_{2}\right)\left(5751\right.$ and $6872 \mathrm{~kg} \mathrm{ha}^{-1}$, respectively). There was saving of water to the extent of $28.5(1271.7 \mathrm{~mm}), 40.4$ per cent $(1085.0 \mathrm{~mm})$ and $36.5(1154.7 \mathrm{~mm})$, by $\mathrm{I}_{1}, \mathrm{I}_{2}$ and $\mathrm{I}_{3}$ respectively compared to recommended practice of irrigation $(1819.7 \mathrm{~mm})$, though there was reduction of grain yield by $5.4,12.5$ and 6.5 per cent, under $\mathrm{I}_{1}, \mathrm{I}_{2}$ and $\mathrm{I}_{3}$ respectively.

\section{Introduction}

Rice (Oryza sativa L.) is the most important staple food crop for more than half of the world population, including regions of high population density and rapid growth. Transplanting is the most dominant and traditional method of establishment in irrigated low land rice. The area under transplanted rice in world is decreasing due to scarcity of water and labour. So, there is need to search for alternate crop establishment methods to increase the productivity of rice (Farooq et al., 2009). Under such circumstances the mechanical transplanting of rice has been considered most promising option, as it saves labour, ensures timely transplanting and attains optimum plant 
density that that contributes to high productivity. Another major concern in rice production systems is the dwindling trend of availability of water resources. The water use efficiency of rice is much lower than other crops. On an average, more than 5000 liters of water are used to produce one kilogram of rice.

In irrigated wet seeded rice culture, water use efficiency on the farm can be increased by applying only the amount of water needed. Among the different methods of water-saving irrigation, the most widely adopted is alternate wetting and drying AWD irrigation method (Li and Barker, 2004).

\section{Materials and Methods}

A field experiment was conducted during kharif, 2014 at Agricultural Research Institute $\left(17^{\circ} 32^{\prime} \mathrm{N} 78^{\circ} 40^{\prime} \mathrm{E}\right.$ and $542.6 \mathrm{~m}$ above mean sea level) Rajendranagar, Hyderabad, Telangana.

The experimental field was sandy loam in texture with a $\mathrm{pH}$ of 8.5 and $\mathrm{EC}$ of $0.56 \mathrm{dSm}^{-1}$, low in organic carbon $(0.41 \%)$ and available nitrogen (166 kg ha-1), high in available phosphorus (82 $\mathrm{kg} \mathrm{ha}^{-1}$ ) and potassium (361 $\mathrm{kg} \mathrm{ha}^{-1}$ ). The experiment was laid out in stripplot design with three different rice cultivation systems as main plot treatments viz., Direct seeding with drum seeder (M1), Transplanting with machine (M2) Conventional transplanting (M3) and four treatments as sub-plot treatments viz., irrigation of $5 \mathrm{~cm}$, when water level falls below $5 \mathrm{~cm}$ from soil surface in field water tube $\left(\mathrm{I}_{1}\right)$, irrigation of $5 \mathrm{~cm}$, when water level falls below $10 \mathrm{~cm}$ from soil surface in field water tube $\left(\mathrm{I}_{2}\right)$, irrigation of $5 \mathrm{~cm}$ at 3 days after disappearance of ponded water $\left(\mathrm{I}_{3}\right)$ and recommended submergence of $2-5 \mathrm{~cm}$ water level as per crop stage $\left(\mathrm{I}_{4}\right)$. Each individual plot was separated with providing buffer channels for proper maintenance of the treatments. The irrigation water measured with the help of water meter.

In different rice cultivation systems sprouted seeds were sown with manually operated rice drum seeder. It drops the seeds at $20 \mathrm{~cm}$ apart in continuous row. In conventional transplanting 25 days old rice seedlings were transplanted, with 2 seedlings per hill ${ }^{-1}$ with spacing of $15 \mathrm{~cm} \times 15 \mathrm{~cm}$ and machine transplanting 17 days old rice seedlings were transplanted, with $30 \mathrm{~cm} \mathrm{x} 12 \mathrm{~cm}$. The crop was fertilized with $120 \mathrm{~kg} \mathrm{~N}, 60 \mathrm{~kg} \mathrm{P}_{2} \mathrm{O}_{5}$ and $40 \mathrm{~kg} \mathrm{~K}_{2} \mathrm{O}$ ha $^{-1}$.

\section{Results and Discussion}

\section{Yield}

Machine transplanting recorded $(14.7 \%)$ and $(10.5 \%)$ higher grain and straw yield (6088 and $6954 \mathrm{~kg} \mathrm{ha}^{-1}$ respectively) which was significantly superior to drum seeding method (5308 and $6295 \mathrm{~kg} \mathrm{ha}{ }^{-1}$ respectively). However conventional transplanting method (5926 and $6886 \mathrm{~kg} \mathrm{ha}^{-1}$ ) was found on par to machine transplanting method with 2.7 and 1.0 per cent variation respectively (Table 1 ).

The lowest yield on other side was recorded with drum seeding of sowing (5308 and 6295 $\mathrm{kg} \mathrm{ha}{ }^{-1}$ respectively) as required crop stand was not maintained in field because of damage by there was rain fall immediately after drum seeding of sprouted seeds and gaps filled afterwards did not compensate the yield loss. These findings are in agreement with the results reported earlier by Anoop Dixit et al., (2007), Manjunatha et al., (2009) and Venkateswarlu et al., (2011).

Recommended submergence of 2-5 cm water level as per crop stage recorded significantly higher grain yield of $6148 \mathrm{~kg} \mathrm{ha}^{-1}$ and was on par with irrigation of $5 \mathrm{~cm}$ at 3 DADPW. 
There were 5.7, 6.9 and 14.3 per cent higher in yield under recommended submergence over irrigation at 3 DADPW and AWDI of 5 $\mathrm{cm}$ at $5 \mathrm{~cm}$ and $10 \mathrm{~cm}$ water level fall in field water tube from surface respectively. Straw yield of $7039 \mathrm{~kg} \mathrm{ha}^{-1}$ was significantly higher under recommended submergence of 2-5 cm water level as per crop stage and was on par with AWDI of $5 \mathrm{~cm}$, when water level falls below $5 \mathrm{~cm}$ from soil surface in field water field tube $\left(6204 \mathrm{~kg} \mathrm{ha}^{-1}\right)$. Similar results were found by Das et al., (2000), Uppal et al., (1991), Kumar et al., (2006). However there was no significant effect of interaction between systems of rice cultivation and irrigation regimes.

\section{Total water applied}

Drum seeding system recorded higher total applied water $(1359.4 \mathrm{~mm})$ among different cultivation systems as compared to CTP $(1325.5 \mathrm{~mm})$ and MTP $(1313.5 \mathrm{~mm})$ (Table 1).

The Field water use depends mostly on irrigation frequency and the quantity of water used by the crop. Water input (irrigation plus effective rainfall) in different treatments varied between $1085 \mathrm{~mm}$ to $1819.7 \mathrm{~mm}$. The recommended submergence of $2-5 \mathrm{~cm}$ water level as per crop stage consumed more water $(1819.7 \mathrm{~mm})$ among different irrigation regimes.

This was followed by irrigation of $5 \mathrm{~cm}$, when water level falls below $5 \mathrm{~cm}$ from soil surface in field water tube $(1271.7 \mathrm{~mm})$ and irrigation of $5 \mathrm{~cm}$ at 3 DADPW $(1154.7 \mathrm{~mm})$. Increased consumptive use of water registered under recommended submergence of $2-5 \mathrm{~cm}$ water level as per crop and irrigation of $5 \mathrm{~cm}$, when water level falls below $5 \mathrm{~cm}$ from soil surface in field water tube was mainly due to more frequent irrigations and increased daily evapotranspiration. It was due to recommended submergence of $2-5 \mathrm{~cm}$ water level as per crop stage, where the number of irrigations was 35 compared with 28 in irrigation of $5 \mathrm{~cm}$, when water level falls below $5 \mathrm{~cm}$ from soil surface in field water tube and 26 in Irrigation of $5 \mathrm{~cm}$ at 3 DADPW. Practicing irrigation of $5 \mathrm{~cm}$, when water level falls below $10 \mathrm{~cm}$ from soil surface in field water tube treatments were recorded least water consumption $(1085 \mathrm{~mm})$ among different irrigation regimes.

Increased dry cycles with reduced evapotranspiration got by this treatment and had negative effect on yields. Similar observations were reported by Ramakrishna (2007).

\section{Water use efficiency (WUE)}

Significantly higher water use efficiency (4.7 $\mathrm{kg} \mathrm{mm}^{-1}$ ) was recorded in case of machine transplanting as compared to drum seeding $\left(4.0 \mathrm{~kg} \mathrm{~mm}^{-1}\right)$ and was on par with conventional transplanting $\left(4.6 \mathrm{~kg} \mathrm{~mm} \mathrm{~mm}^{-1}\right)$. This was due to higher grain yield and comparatively lower irrigation water used in MTP (Table 1).

The different irrigation practices significantly influenced the WUE of the rice crop. The WUE was higher in the treatment with irrigation of $5 \mathrm{~cm}$ when water level falls below $10 \mathrm{~cm}$ from soil surface in field water tube $\left(\mathrm{I}_{2}\right)$, which registered $4.9 \mathrm{~kg} \mathrm{~mm}^{-1}$ and was on par with irrigation of $5 \mathrm{~cm}$ at 3 DADPW (4.8 $\mathrm{kg} \mathrm{mm}^{-1}$ ) and irrigation of $5 \mathrm{~cm}$ when water level falls below $5 \mathrm{~cm}$ from soil surface in field water tube with $\left(4.5 \mathrm{~kg} \mathrm{~mm}^{-1}\right)$. The lowest WUE was accounted with recommended submergence of 2-5 cm water level as per crop stage $\left(\mathrm{I}_{4}\right)$, which recorded $3.5 \mathrm{~kg} \mathrm{~mm}^{-1}$. The higher water use efficiency (WUE) can be increased either by increasing yield or by maintaining the same yield level with reduced quantity of water input. 
Table.1 Yield $\left(\mathrm{kg} \mathrm{ha}^{-1}\right)$, Applied Water $(\mathrm{mm})$, Total water $(\mathrm{mm})$ and Water Productivity $\left(\mathrm{kg} \mathrm{mm}^{-1}\right)$ of rice as influenced by different Systems of cultivation and irrigation regimes

\begin{tabular}{|c|c|c|c|c|c|}
\hline Treatment & \multicolumn{2}{|c|}{$\begin{array}{c}\text { Yield } \\
\left(\mathrm{kg} \mathrm{ha}^{-1}\right)\end{array}$} & $\begin{array}{c}\text { Applied } \\
\text { Water } \\
(\mathbf{m m}) \\
\end{array}$ & $\begin{array}{l}\text { Total } \\
\text { water } \\
(\mathbf{m m}) \\
\end{array}$ & $\begin{array}{c}\text { Water } \\
\text { Productivity } \\
\left(\mathrm{kg} \mathrm{mm}^{-1}\right)\end{array}$ \\
\hline \multicolumn{6}{|l|}{ Main plot - systems of cultivation } \\
\hline $\mathbf{M}_{2-}$ Transplanting with machine & 6088 & 6954 & 1100 & 1313 & 4.7 \\
\hline $\mathbf{M}_{3}$ - Conventional transplanting & 5926 & 6886 & 1087 & 1325 & 4.5 \\
\hline \multicolumn{6}{|l|}{ Sub plot - Irrigation regimes } \\
\hline $\begin{array}{l}\mathbf{I}_{1^{-}} \text {Irrigation of } 5 \mathrm{~cm} \text {, when water level falls below } 5 \mathrm{~cm} \text { from soil surface in } \\
\text { field water tube }\end{array}$ & 5751 & 6872 & 1063 & 1271 & 4.5 \\
\hline $\begin{array}{l}\text { I }_{2} \text { - Irrigation of } 5 \mathrm{~cm} \text {, when water level falls below } 10 \mathrm{~cm} \text { from soil surface in } \\
\text { field water tube }\end{array}$ & 5379 & 6204 & 813 & 1085 & 4.9 \\
\hline C.D $(\mathrm{P}=0.05)$ & 334 & 236 & & & 0.6 \\
\hline \multicolumn{6}{|l|}{ Interaction between different systems of cultivation and irrigation regimes } \\
\hline \multicolumn{6}{|l|}{ Irrigation regimes at same level of systems of cultivation } \\
\hline SEm \pm & 239 & 182 & & & 0.3 \\
\hline C.D $(\mathrm{P}=0.05)$ & NS & NS & & & NS \\
\hline \multicolumn{6}{|l|}{ Different systems of cultivation at same level of irrigation regimes } \\
\hline SEm \pm & 238 & 203 & & & 0.3 \\
\hline C.D $(\mathrm{P}=0.05)$ & NS & NS & & & NS \\
\hline
\end{tabular}


In the present study also, reduction in consumptive water use under irrigation of 5 $\mathrm{cm}$ when water level falls below 5 and $10 \mathrm{~cm}$ from soil surface in field water tube and irrigation of $5 \mathrm{~cm}$ at 3 DADPW coupled with the maintenance of yield at an optimum level increased the WUE. WUE under AWDI of 5 $\mathrm{cm}$ submergence depth with $10 \mathrm{~cm}$ drop of water level in the field tube treatment was 40 per cent compared to the recommended submergence of $2-5 \mathrm{~cm}$ water level as per crop stage. Irrigation of $5 \mathrm{~cm}$, when water level falls below $5 \mathrm{~cm}$ from soil surface in field water tube and irrigation of $5 \mathrm{~cm}$ at 3 DADPW treatments compared to the conventional method of irrigation practice recorded higher WUE of 28.5 and 36.1 per cent over recommended practice due to reduction in consumptive use.

Machine transplanting recorded $(14.7 \%)$ and $(10.5 \%)$ higher grain and straw yield respectively which was significantly superior to drum seeding method. However conventional transplanting method was found on par to machine transplanting method with 2.7 and 1.0 per cent variation respectively. Significantly higher water use efficiency (4.7 $\mathrm{kg} \mathrm{mm}{ }^{-1}$ ) was recorded in case of machine transplanting as compared to drum seeding $\left(4.0 \mathrm{~kg} \mathrm{~mm} \mathrm{~mm}^{-1}\right)$ and was on par with conventional transplanting $\left(4.6 \mathrm{~kg} \mathrm{~mm}^{-1}\right)$. There was saving of water by $36.5,28.5$ and 40.4 per cent respectively compared to recommended practice of irrigation, though there was reduction of grain yield by $5.4,6.5$ and 12.3 per cent due to irrigation of $5 \mathrm{~cm}$ at 3 DADPW, irrigation of $5 \mathrm{~cm}$ when water falls below $5 \mathrm{~cm}$ from soil surface in field water tube and irrigation of $5 \mathrm{~cm}$ when water falls below $10 \mathrm{~cm}$ from soil surface in field water tube respectively.

\section{Acknowledgments}

I humbly extend my profound gratitude to my Professors, staff of Water Technology centre and Rice section ARI Rajendranagar, College of Agriculture, PJTSAU, Hyderabad for their constant support and valuable suggestions offered during the course of research work.

\section{References}

Anoop Dixit, R., Khurana, Jaskarn Singh, and Gurusahib Singh. 2007. Comparative performance of different paddy transplanters developed in India - A Review. Agricultural reviews. 28 (4): 262-269.

Das, J. C., Sarmah, N. N., Bakakoty, P. K., and Choudhury, A. K. 2000. Effects of irrigation regimes on transplanted summer (ahu) rice in Assam. Annals of Agricultural Research. 21 (4): 481-484.

Farooq, M., Kobayashi, N., Wahid, A., and Shadhzad M.A. Basra. 2009. Strategies for producing more rice with less water. Advances in Agronomy. 101: 351-388.

Kumar, R. P., Singh G. K. and Singh A. K., 2006. Irrigation schedule for better growth, development and yield of hybrid rice (Oryza sativa L.). Crop Research. 32(91): 6-10.

Li, Y. H., and Barker, R. 2004. Increasing water productivity for paddy irrigation in China. Paddy Water Environment. 2 (4): 187-193.

Manjunatha, M.V., Masthana Reddy, B. G., Shsshidhar, S. D and Joshi, V.R. 2009. Studies on the performance of selfpropelled rice transplant and its effect on crop yield. Karnataka Journal of Agricultural Sciences. 22 (2): 385-387

Ramakrishna, Y., Singh, S and Parihar, S. S. 2007. Influence of irrigation regime and nitrogen management on productivity, nitrogen uptake and water use by rice (Oryza sativa). Indian Journal of Agronomy. 52 (2): 102-106.

Uppal, H. S., Cheema, S. S and Walia, A. S. 1991. Irrigation need of transplanting rice (Oryza sativa) in non-cracking soil. Indian Journal of Agricultural Sciences. 
61 (9): 634-636.

Venkateswarlu, E., Sambasiva Rao, N and Rama Prasad, D. 2011. On farm evaluation of mechanical transplanting of rice (Oryza sativa) against traditional method. The Andhra Agricultural Journal. 58 (1): 9-11.

\section{How to cite this article:}

Sathish, A., K. Avil Kumar, P. Raghu Rami Reddy and Uma Devi, M. 2017. Effect of Different Crop Establishment Methods and Irrigation Regimes on Rice (Oryza sativa L.) Yield and Water Use Efficiency. Int.J.Curr.Microbiol.App.Sci. 6(9): 90-95. doi: https://doi.org/10.20546/ijcmas.2017.609.010 